\title{
The Importance of Systematically Reporting and Reflecting on eHealth Development: Participatory Development Process of a Virtual Reality Application for Forensic Mental Health Care
}

Hanneke Kip ${ }^{1,2}$, MSc; Saskia M Kelders ${ }^{1,3}, \mathrm{PhD}$; Yvonne H A Bouman ${ }^{2}, \mathrm{PhD}$; Lisette J E W C van Gemert-Pijnen ${ }^{1,4}$, Prof Dr

\footnotetext{
${ }^{1}$ Centre for eHealth and Wellbeing Research, Department of Psychology, Health and Technology, University of Twente, Enschede, Netherlands

${ }^{2}$ Department of Research, Stichting Transfore, Deventer, Netherlands

${ }^{3}$ Optentia Research Focus Area, North-West University, Vanderbijlpark, South Africa

${ }^{4}$ Faculty of Medical Sciences, Universitair Medisch Centrum Groningen, Groningen, Netherlands
}

Corresponding Author:

Hanneke Kip, MSc

Centre for eHealth and Wellbeing Research

Department of Psychology, Health and Technology

University of Twente

Drienerlolaan 5

Enschede, $7522 \mathrm{NB}$

Netherlands

Phone: 31534896536

Email: h.kip@utwente.nl

\section{Abstract}

Background: The use of electronic health (eHealth) technologies in practice often is lower than expected, mostly because there is no optimal fit among a technology, the characteristics of prospective users, and their context. To improve this fit, a thorough systematic development process is recommended. However, more knowledge about suitable development methods is necessary to create a tool kit that guides researchers in choosing development methods that are appropriate for their context and users. In addition, there is a need for reflection on the existing frameworks for eHealth development to be able to constantly improve them.

Objective: The two main objectives of this case study were to present and reflect on the (1) methods used in the development process of a virtual reality application for forensic mental health care and (2) development model that was used: the CeHRes Roadmap (the Centre for eHealth Research Roadmap).

Methods: In the development process, multiple methods were used to operationalize the first 2 phases of the CeHRes Roadmap: the contextual inquiry and value specification. To summarize the most relevant information for the goals of this study, the following information was extracted per method: (1) research goal, (2) explanation of the method used, (3) main results, (4) main conclusions, and (5) lessons learned about the method.

Results: Information on 10 methods used is presented in a structured manner. These 10 methods were stakeholder identification, project team composition, focus groups, literature study, semistructured interviews, idea generation with scenarios, Web-based questionnaire, value specification, idea generation with prototyping, and a second round of interviews. The lessons learned showed that although each method added new insights to the development process, not every method appeared to be the most appropriate for each research goal.

Conclusions: Reflection on the methods used pointed out that brief methods with concrete examples or scenarios fit the forensic psychiatric patients the best, among other things, because of difficulties with abstract reasoning and low motivation to invest much time in participating in research. Formulating clear research questions based on a model's underlying principles and composing a multidisciplinary project team with prospective end users appeared to be important in this study. The research questions supported the project team in keeping the complex development processes structured and prevented tunnel vision. With regard to the CeHRes Roadmap, continuous stakeholder involvement and formative evaluations were evaluated as strong points. A suggestion to further improve the Roadmap is to explicitly integrate the use of domain-specific theories and models. To create 
a tool kit with a broad range of methods for eHealth development and further improve development models, studies that report and reflect on development processes in a consistent and structured manner are needed.

(J Med Internet Res 2019;21(8):e12972) doi: 10.2196/12972

\section{KEYWORDS}

eHealth; technology development; virtual reality; forensic psychiatry; community-based participatory research; human-centered design; case study

\section{Introduction}

Electronic health (eHealth) — a technology to support health, well-being, and health care - can offer many benefits, such as increased quality of care, easily accessible health care, and increased self-management [1]. However, these benefits are often not fully realized in practice [2]. A possible explanation for this is that technology does not optimally fit the needs, wishes, and characteristics of the involved end users and their context [3-5]. A way to improve this fit is thorough participatory eHealth development in which potential end users are structurally involved in the development process [1,6-8]. Consequently, many efforts have been made to create models, approaches, and guidelines for development of eHealth technologies. Examples are the CeHRes Roadmap (the Centre for eHealth Research Roadmap) [9], the person-based approach [10], the accelerated creation-to-sustainment model [11], intervention mapping [12], the persuasive system design model [13], and the agile science approach [14]. Most of these models and approaches do not offer concrete prescriptions for ready-to-use research methods that fit specific contexts and people. Instead, they present abstract guidelines for development to support researchers in shaping their development process. Although a step-by-step, detailed prescription of a specific development process does not seem feasible because of different characteristics of contexts, people, and technologies, there does seem to be a need for more knowledge and guidelines on how to apply these models in practice [14]. To support researchers in operationalizing development models, we propose that a general tool kit with a broad range of eHealth development methods might be developed. Such a tool kit can provide an overview of broad-range development methods and guidelines on when and how to apply them. In this way, it can support researchers in choosing appropriate methods for the context and end users with which they are working and different phases of their development process. Using a tool kit can prevent other researchers from having to reinvent the wheel and result in more efficient and better substantiated development processes.

To create a tool kit, more generalizable knowledge on eHealth development methods is necessary. To build this knowledge base, more case studies that explain and reflect on specific development methods used seem to be necessary [15]. On top of that, there also should be more critical reflection on eHealth development models [2,10], mostly to be able to constantly improve these models to keep them in line with the most recent insights. Although there are several studies that describe development processes of eHealth technologies [16-20], there seems to be no standardized way of reporting and reflecting on the methods used. Also, an in-depth critical reflection on the development model used is often lacking. To fill these gaps in the literature, this case study presents and reflects on the development process of a virtual reality (VR) application for forensic mental health care. This study had 2 main goals. First, it aimed to increase knowledge on suitable methods for participatory eHealth development. This contributes to creating the aforementioned tool kit. Second, it aimed to reflect on the development model used to guide the process: the CeHRes Roadmap. Combined with other studies that reflect on this model, this can result in further improvement of the Roadmap.

\section{Methods}

\section{The CeHRes Roadmap}

In this study, the aforementioned CeHRes Roadmap [9] was applied to shape the development process of the VR application. This development model specifically focuses on eHealth development, implementation, and evaluation with structural stakeholder involvement $[1,6,9]$. The Roadmap has been proven useful for eHealth development in multiple settings [16,18,21] and seems to be suitable for development in complex contexts [9], such as forensic mental health care. The Roadmap is based on 5 principles that are also acknowledged by other studies on eHealth development:

- eHealth development should be a participatory process - structurally and actively involving stakeholders during development is important [7,10,12,21].

- eHealth should not be seen as a separate, stand-alone tool but has to be integrated in a health care context, which also implies changes in the way health care is delivered $[5,22,23]$.

- eHealth development and implementation should be intertwined; implementation is a very complex activity that should be accounted for from the start of the development process [24,25].

- eHealth technologies should be based on theories from persuasive design, which can be used to support behavior and attitude change via technology [13].

- Continuous, formative evaluation in eHealth development is important to enable creating by evaluation $[7,8,14,26]$. 
Figure 1. The CeHRes Roadmap (the Centre for eHealth Research Roadmap) [9].

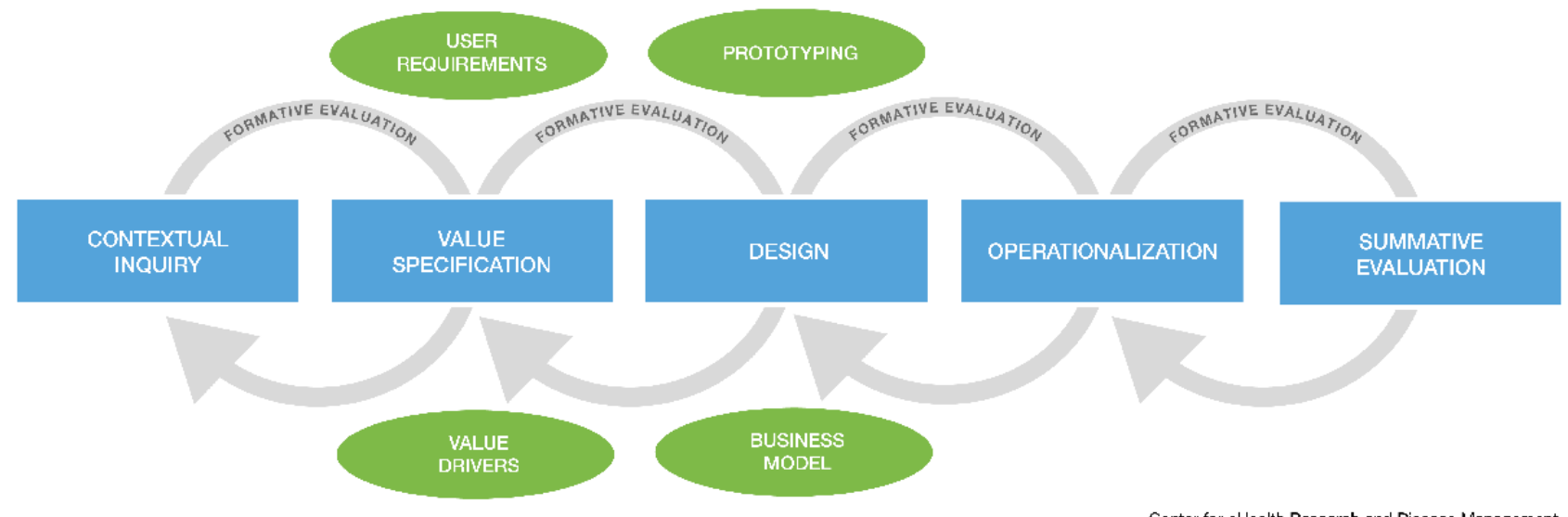

These principles are translated into a model with 5 phases with accompanying goals, which are presented in Figure 1 [9]. This model can be used by developers to shape their development approach $[3,6,9]$. As the aim of this paper is to describe the development of eHealth technology and not the implementation or evaluation, the focus lies on the first 2 phases of the Roadmap: the contextual inquiry and value specification. These phases aim to create a thorough foundation for a technology and account for the interrelationship among the context, the people involved, and the technology. In the contextual inquiry, relevant stakeholders are identified, their roles, tasks, and opinions are analyzed, and the current situation and its weak and strong points are described to determine if and in what way technology can contribute. In the value specification, the values of the key stakeholders have to be identified and prioritized to determine what the added value of a technology should be. These values have to be translated into specific requirements that state what the technology should be able to do and look like [6].

\section{Case}

Due to the involvement of 2 of the researchers in the development process, this research can be labeled as an action study. In this study, the development process of a VR application for the treatment of forensic psychiatric patients is presented. This project was initiated and mostly took place at Transfore, a forensic hospital in the east of the Netherlands, which offers forensic mental health care to both in- and outpatients. Forensic mental health care is a complex branch of mental health care, which is situated at the intersect between mental health care and the law because it deals with the combination of mental illness and delinquent behavior. In forensic mental health care, inpatients who reside in a closed setting and outpatients who are living at home are treated for sexual or aggressive criminal behavior [20,21]. A primary goal is to prevent criminal recidivism by means of treatment of offense-related factors, such as antisocial behavior or coping skills. Owing to their low motivation for treatment, low educational levels, and comorbid psychiatric disorders [22-24], forensic psychiatric patients can be characterized as a vulnerable patient population $[25,26]$, which can be hard to include in research [27].

Multiple studies have pointed out the potential of VR for the assessment and treatment of forensic psychiatric patients
[27-29]. VR offers the possibility to practice coping skills instead of talking about them, can be used to overcome practical issues for inpatients residing in clinics, and can enable therapists to observe patients' reactions to offense-related stimuli or situations, such as children, drugs, or aggressive persons [29-31]. In VR, users enter computer-generated worlds that substitute their real-world sensory experiences with virtual ones [32], resulting in a feeling of presence: a sense of actually being in a virtual place [33]. Although VR applications have been used in mental health care, especially in exposure therapy for phobias [34], not much is known about its application in the treatment of forensic psychiatric patients [27]. Furthermore, little attention has been paid to how VR interventions should be developed for mental health care in general [32]. In our recent systematic review, we found that there are hardly any studies that discuss the development of technologies for forensic mental health [28]. However, especially in such a complex context in which there is little experience with the application of VR, thorough development is important $[10,27]$. Consequently, a thorough contextual inquiry and value specification to provide a good foundation for the application were especially important.

\section{Materials and Procedures}

In this study, multiple methods were used to operationalize the first 2 phases of the CeHRes Roadmap. The development process started with the contextual inquiry. In this phase, the stakeholders were identified, a literature review was conducted, and a multidisciplinary project team to coordinate the project was constituted. Also, focus groups and interviews with forensic patients and therapists were held. In the value specification phase, 6 scenarios with concepts for VR applications were generated by the multidisciplinary project team. These concepts were presented to the patients, therapists, and stakeholders in a Web-based questionnaire. Next, values were formulated and used to create a concept for a VR app. This concept was visualized in a low-fidelity prototype and presented to the patients and therapists in an interview to examine their opinions and preferences. These activities were not performed sequentially: several methods were conducted alongside each other or were updated throughout the process [18]. Figure 2 provides an overview of the methods used in the development process. The arrows represent the iterative nature of the process and show that the methods and results of the contextual inquiry 
and value specification are not strictly separated but overlap. For more in-depth information about the results of the interviews and questionnaire, we refer readers to 2 other papers $[29,30]$ that focus more on the content of the results and potential of VR for forensic mental health instead of a reflection on the methods and overall development process.

Figure 2. An overview of the used methods in the contextual inquiry and value specification phases of this study.

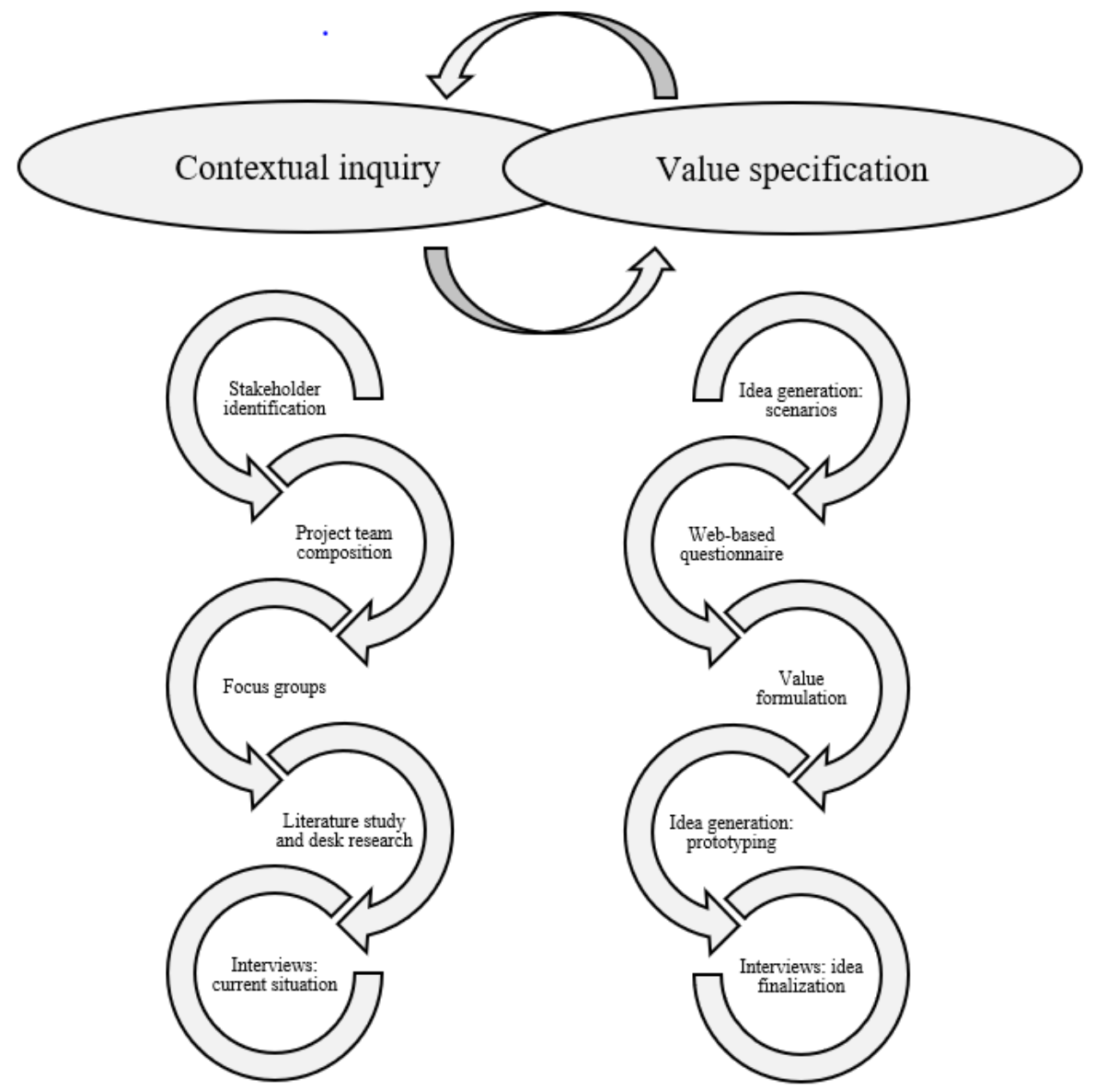

\section{Analysis}

To reflect on the suitability of the methods and overall development process, we provided the most relevant information about each research method in a comprehensive table. The aim of this table is to present the goals, methods, results, and experiences with each method as clearly and concisely as possible. For each development method, the following information is reported:

- Research question: The research question for the development activity.

- Method: The name of the method, including the most relevant methodological information.

- Target group: If applicable, a description of the target group of which the data were collected and characteristics of the participants.
- Main results: A summary of the most important results and, if necessary, a reference to a Multimedia Appendix with further information about these results.

- Conclusions: The main conclusions and recommendations for further steps of the development process, which were drawn based on the results.

- Lessons learned: A reflection on the suitability of the method for the specific development phase, target group, and research question.

\section{Results}

\section{Contextual Inquiry}

In the contextual inquiry, we generated an overview of relevant stakeholders and their roles and tasks. Furthermore, the current situation and its points of improvement were analyzed to determine if and in what way VR could contribute to treatment in forensic mental health [6]. We used multiple methods that are provided in Table 1 below. 
Table 1. An overview of the methods and outcomes and reflection on these methods of the contextual inquiry.

\begin{tabular}{ll}
\hline Research goal & Method \\
\hline $\begin{array}{l}\text { Creating an overview } \\
\text { of people and organi- } \\
\text { zations who had a } \\
\text { stake in the develop- } \\
\text { ment process }\end{array}$ & $\begin{array}{l}\text { Stakeholder identifica- } \\
\text { search, expert recom- } \\
\text { mendations, and } \\
\text { snowball sampling } \\
\text { [31], constantly updat- } \\
\text { ed throughout the } \\
\text { project }\end{array}$
\end{tabular}

Constituting a multidisciplinary project team comprising patients, therapists, managers, and researchers to coordinate the project
Project team composition: In total, 5 potential end users (patients and therapists) were asked to join the team by the policy advisor of the organization in which the project took place (convenience sampling) to coordinate the project [6]. A total of 2 researchers were added for methodological and theoretical knowledge

Target
group

Main results

Conclusions

Lessons learned

Not appli- Identification of a cable

broad range of stakeholders, such as end users, financers of care, knowledge institutes, and other forensic care organizations-see Multimedia Appendix 1 (1.1) for a visualization of the identified stakeholders
Stakeholder identification was useful to identify potential financers, participants, or institutions for data collection and to look for potential development partners

Not appli- The project team with cable 2 patients, 3 therapists, 2 researchers, and 1 policy advisor $(n=8)$ was responsible for content-related and practical activities, such as structuring the development process, setting up studies, and accompanying research goals, interpreting results, decision making, and planning
The multidisciplinary project team was found to be essential for the coordination of the project, mostly because of the integration of different perspectives.
- This method served well as a starting point for the project, but as indepth information about (key) stakeholders was lacking, additional research into stakeholder perspectives was necessary, for example, via interviews.

- The stakeholder identification was constantly revised over the course of the project to keep it up-to-date.

- The identification proved to be important in preventing the relevant stakeholders from being overlooked in the development process and also in supporting the researchers in identifying participants for studies.

- Including potential end users in the project team was useful to ensure that decisions were aligned with their perspective. In hindsight, the team might have benefited from someone with more technical

knowledge on $\mathrm{VR}^{\mathrm{a}}$, for example, a developer.

- Practical issues can influence the project team composition, for example, sometimes therapists or patients did not have enough time. It was important to make agreements on what to do when this occurred.

- $\quad$ Structure was needed to keep members involved: setting regular meetings, clear communication in between meetings, and keeping minutes of meetings. Coordination by a project manager was important to achieve this.

- The project team members had individual, concrete, and specific tasks that helped in keeping everyone actively involved.

- $\quad$ Patients indicated that participating in the project team gave them a sense of purpose and helped them with their treatment. 


\begin{tabular}{|c|c|c|c|}
\hline Research goal & Method & $\begin{array}{l}\text { Target } \\
\text { group }\end{array}$ & Main results \\
\hline $\begin{array}{l}\text { Determining how far } \\
\text { there is support and } \\
\text { enthusiasm for } \mathrm{VR}^{\mathrm{a}} \text { in } \\
\text { forensic mental health } \\
\text { care and identifying } \\
\text { the ideas of therapists } \\
\text { and patients about po- } \\
\text { tential ways of using } \\
\text { VR in treatment }\end{array}$ & $\begin{array}{l}\text { Focus groups: Struc- } \\
\text { ture: presentations on } \\
\text { VR by } 2 \text { companies, } \\
\text { trying out VR by par- } \\
\text { ticipants, individually } \\
\text { coming up with ideas } \\
\text { about VR in treat- } \\
\text { ment, creating ideas } \\
\text { in groups of } 4 \text {, present- } \\
\text { ing the ideas to the } \\
\text { entire group ; The du- } \\
\text { ration of the focus } \\
\text { groups was } 2 \text { hours } \\
\text { and data were collect- } \\
\text { ed via researchers' } \\
\text { notes and templates } \\
\text { filled in by the partici- }\end{array}$ & $\begin{array}{l}\text { Patients } \\
(n=14) \\
\text { and thera- } \\
\text { pists } \\
(n=23)\end{array}$ & $\begin{array}{l}\text { Most participants } \\
\text { were very positive } \\
\text { about VR. There was } \\
\text { a broad range of ideas } \\
\text { about using VR, for } \\
\text { example, to improve } \\
\text { skills, enhance insight } \\
\text { by therapists or loved } \\
\text { ones, or treat specific } \\
\text { disorders, such as } \\
\text { psychosis or posttrau- } \\
\text { matic stress disorder. } \\
\text { See Multimedia Ap- } \\
\text { pendix } 1 \text { (1.3) for a } \\
\text { table with the main } \\
\text { results of the focus } \\
\text { groups. }\end{array}$ \\
\hline
\end{tabular}

pants (see Multimedia Appendix 1: 1.2).
Conclusions $\quad$ Lessons learned

There appeared to be $\quad$ Focus groups were a good and effimany possibilities, but further specification and insight into why and how VR should be used was required cient way to start this broad, complex project with many possible outcomes, mostly to get an idea of attitudes and potential end users.

- These focus groups aimed to generate idea, so provided little in-depth information about needs and goals. It was necessary to complement them with other methods, such as interviews.

- The way this focus group was set up was seen as a strong point: there was a clear structure without much steering on content, which enabled all participants to brainstorm freely and individually. This resulted in a very broad range of ideas, which was relevant for this phase of the development process.

- It was relatively easy to find participants for the focus groups. An important reason for this seemed to be the possibility to learn more about and try out VR.
Gaining an overview of all studies and current initiatives concerning VR in treatment of (forensic) psychiatric patients
Literature study and desk research: Scientific database, search string (virtual reality OR VR OR augmented reality OR AR) AND (treatment OR intervention OR therapy) AND (forensic OR offend* OR crim*) and searching the internet, talking to stakeholders, and visiting conferences
Not appli- In July 2017, only 6 cable relevant studies were found, mostly focused on the assessment of sexual delinquents [32-35] or general literature studies on VR [36,37]. Multiple ongoing projects were identified via desk research but with no accompanying scientific able products publications or avail-
Not much is known about VR in forensic mental health care in both practice and research, so there appeared to be a need for a bottom-up development process to identify why and in what way VR could be used
- Especially, desk research proved to be relevant for the project because there were no publications (yet) about many recent, ongoing initiatives/projects.

- The strategy for desk research could have been more structured, for example, by creating an activity plan and planning recent updates of desk research.

- It was important to look outside of the focus of the project (eg, studies on VR in general), either by conducting a literature study (which is time consuming) or by searching for published reviews or metaanalyses.

- It might have been useful to systematically collect the literature on theories and models on delinquent behavior, as in this project, it was done in a more ad hoc manner.
Identifying points of improvement in the existing forensic mental health treatment of in- and outpatients and possible applications of VR, which could improve the current situation, according to therapists and patients
Interviews: current situation: The first part of the interview scheme focused on points of improvement of the current treatment (regardless of VR) [21], the second part focused on the possibilities of VR to improve the current treatment. The outcomes of the focus groups were used to structure the interview scheme
Thera-

pists

$(n=8)$ and patients $(n=3)$, working or treated at multiple locations of Trans-

fore, the forensic hospital.
The interviews gave much information about why and how VR could be of added value. However, there were still too many possible directions to make a grounded decision about the goal and content of VR. Additional research into the needs and wishes of end users was required 


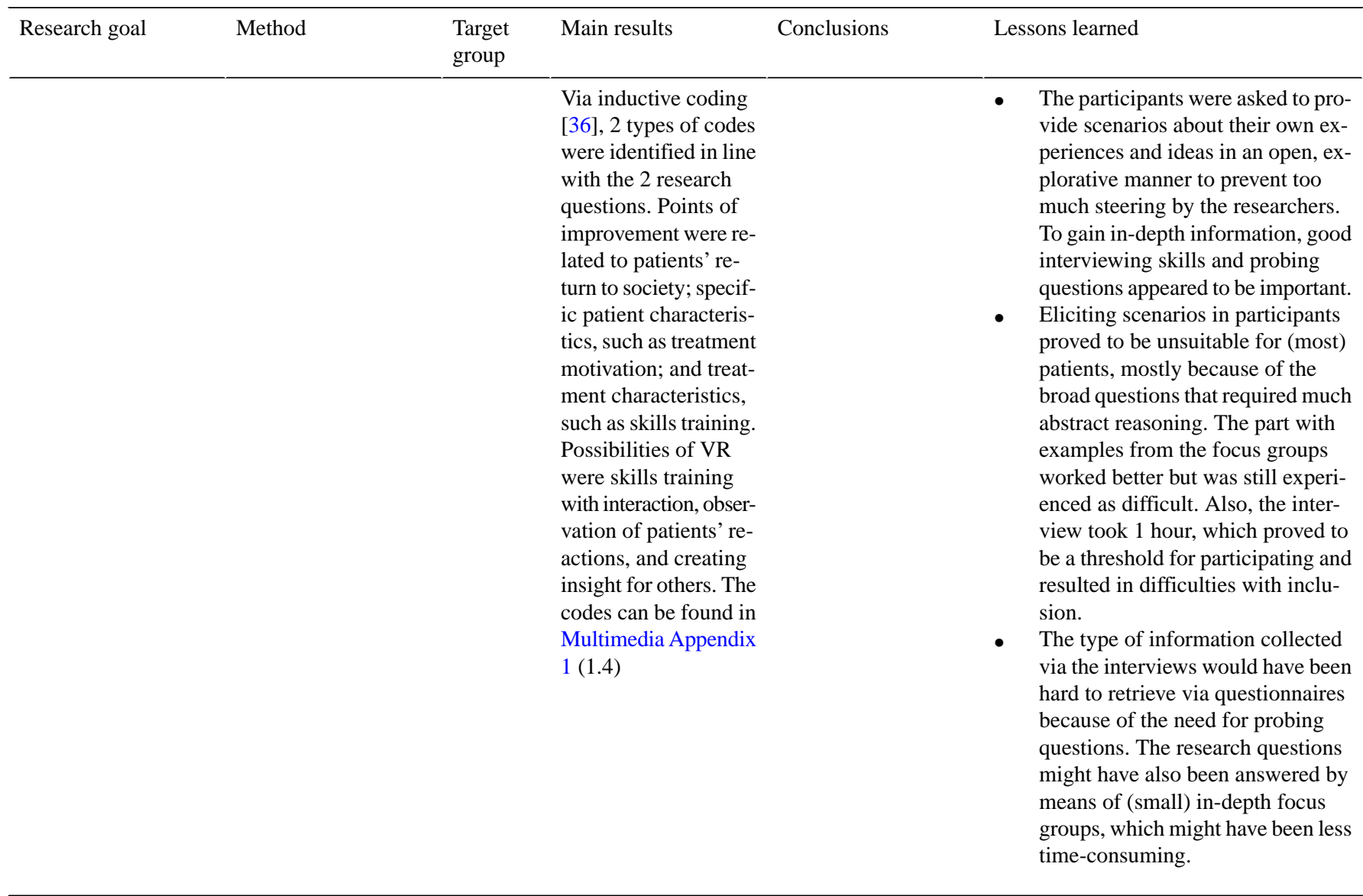

${ }^{\mathrm{a}}$ VR: virtual reality.

\section{Value Specification}

In the value specification phase, the outcomes of the contextual inquiry were used to further specify what the added value of a technology should be according to the key stakeholders. Again, multiple methods were used to identify the stakeholders' preferences and opinions on VR in forensic treatment and prototypes to specify these abstract values were created. These methods are provided in Table 2. 
Table 2. An overview of the methods and outcomes and reflection on these methods of the value specification.

\begin{tabular}{|c|c|c|c|c|c|}
\hline Research goal & Method & $\begin{array}{l}\text { Target } \\
\text { group }\end{array}$ & Main results & Conclusions & Lessons learned \\
\hline $\begin{array}{l}\text { Generating multiple } \\
\text { ideas on the use of } \\
\mathrm{VR}^{\mathrm{a}} \text { in forensic men- } \\
\text { tal health care, based } \\
\text { on the outcomes of } \\
\text { the contextual inquiry }\end{array}$ & $\begin{array}{l}\text { Idea generation-sce- } \\
\text { narios: In } 3 \text { sessions, } \\
\text { all project team mem- } \\
\text { bers individually } \\
\text { brainstormed about } \\
\text { ideas for VR applica- } \\
\text { tions. The } 6 \text { most } \\
\text { promising ideas were } \\
\text { worked out in a tem- } \\
\text { plate (see Multimedia } \\
\text { Appendix 1: } 1.5 \text { ) by } \\
\text { multiple project team } \\
\text { members. On the ba- } \\
\text { sis of these templates, } \\
\text { scripts were written } \\
\text { and } 6 \text { short videos } \\
\text { were filmed }\end{array}$ & $\begin{array}{l}\text { Not appli- } \\
\text { cable }\end{array}$ & $\begin{array}{l}\text { A short video was } \\
\text { created for each of the } \\
6 \text { ideas. All videos } \\
\text { had the same underly- } \\
\text { ing structure: the goal } \\
\text { of VR, its use during } \\
\text { treatment, an exam- } \\
\text { ple, and the desired } \\
\text { outcomes. The videos } \\
\text { (with English subti- } \\
\text { tles) can be watched } \\
\text { on YouTube [38]. An } \\
\text { example of a scenario } \\
\text { can be found in Multi- } \\
\text { media Appendix } 1 \\
\text { (1.6) }\end{array}$ & $\begin{array}{l}\text { The videos made clear } \\
\text { that there are a lot of } \\
\text { promising possibilities } \\
\text { for VR in forensic } \\
\text { mental health, so it } \\
\text { appeared to be neces- } \\
\text { sary to make decisions } \\
\text { about what to priori- } \\
\text { tize and why }\end{array}$ & $\begin{array}{l}\text { - The structured approach in which } \\
\text { multiple templates were used } \\
\text { worked well in this project: it } \\
\text { forced all different members of the } \\
\text { project team to work and think in a } \\
\text { similar way. } \\
\text { Each member of the project team } \\
\text { had a clear role with individual re- } \\
\text { sponsibilities. This was experienced } \\
\text { as helpful in motivating the team } \\
\text { members and ensuring that all of } \\
\text { their perspectives were present in } \\
\text { the } 6 \text { ideas. } \\
\text { Creating scripts and videos was } \\
\text { very time-consuming, so motivated } \\
\text { members who are willing to invest } \\
\text { time and effort and enough budget } \\
\text { were necessary preconditions for } \\
\text { making videos. }\end{array}$ \\
\hline
\end{tabular}

Identifying (1) the preferences of stakeholders of the 6 ideas and (2) the stakeholders' values regarding VR in forensic mental health care
Web-based questionnaire: After asking sociodemographic questions, the 6 videos were presented to the participants in random order. After each video, the PII ${ }^{\mathrm{b}}$ $[39,40]$ a question about the participant's grade for the idea, and 3 open questions on positive points, points of improvement, and suggestions for the idea were provided
Patients There were no signifi- The results of the $(n=19) ; \quad$ cant differences be- questionnaire were therapists tween the grades and mostly in line with the $(n=89)$; PII scores for ideas. A interviews but providother broad range of posi- ed more detailed and stakehold- tive and negative as- specific information, ers pects and remarks for example, how VR $(n=38)$, were identified via in- should be personalsuch as ductive coding. These ized and which skills parole of- can be found in Multi- should be trained ficers or media Appendix 1 researchers from different

Dutch forensic institutions
- $\quad$ The answers of the patients fitted the research questions of the questionnaire better than the answers that were given by patients in the interviews. This indicated that the concrete, scenario-based videos were a better way to include the patient perspective than the broad, abstract interviews.

- Although the goal was to make this method less time-consuming, filling in the questionnaire still took about 30 minutes, which might explain why a large share of the participants (55.4\%) did not fully complete it. A shorter questionnaire might have led to more response but also would mean that less information would have been retrieved.

- The quantitative measures indicated no major differences between opinions about ideas. Although it was not clear if this was an issue regarding validity or if there actually were no differences, it was still useful to ask for a grade for each idea. The PII was not of added value in this questionnaire.

- Although this method proved to be useful to further specify previously found results, it would not have been suitable as an initial method to gather in-depth information, partly because no probing questions could be asked, and answers were relatively short. 


\begin{tabular}{|c|c|c|c|c|c|}
\hline Research goal & Method & $\begin{array}{l}\text { Target } \\
\text { group }\end{array}$ & Main results & Conclusions & Lessons learned \\
\hline $\begin{array}{l}\text { Formulating values } \\
\text { that capture what the } \\
\text { added value of the } \\
\text { technology should be } \\
\text { for people and con- } \\
\text { text, according to the } \\
\text { stakeholders }\end{array}$ & $\begin{array}{l}\text { Value formulation: } \\
\text { On the basis of all } \\
\text { previous results, } 2 \text { re- } \\
\text { searchers created at- } \\
\text { tributes that summa- } \\
\text { rized the needs or } \\
\text { wishes of stakeholders } \\
\text { [17]. On the basis of } \\
\text { categories of related } \\
\text { attributes, accompany- } \\
\text { ing values that stated } \\
\text { what VR should } \\
\text { achieve, improve, or } \\
\text { add according to the } \\
\text { stakeholders [6,17] } \\
\text { were formulated. The } \\
\text { values were discussed } \\
\text { by the project team } \\
\text { and minor adjust- } \\
\text { ments were made ac- } \\
\text { cordingly }\end{array}$ & $\begin{array}{l}\text { Not appli- } \\
\text { cable }\end{array}$ & $\begin{array}{l}\text { A total of } 43 \text { attributes } \\
\text { and } 13 \text { values were } \\
\text { formulated. An exam- } \\
\text { ple of how a value } \\
\text { was created can be } \\
\text { found in Multimedia } \\
\text { Appendix } 1 \text { (1.8). The } \\
\text { following values were } \\
\text { formulated: fit with } \\
\text { patient; improvement } \\
\text { of skills; insights into } \\
\text { behavior, thoughts, } \\
\text { and feelings; bridge } \\
\text { between treatment } \\
\text { room and practice; } \\
\text { generalization of } \\
\text { skills to daily life; } \\
\text { safety; treatment moti- } \\
\text { vation; unique addi- } \\
\text { tion to current treat- } \\
\text { ment; ease of use } \\
\text { within treatment; coop- } \\
\text { eration between pa- } \\
\text { tient and therapist; } \\
\text { wide applicability; af- } \\
\text { fordability; and con- } \\
\text { stant adaptation of the } \\
\text { application }\end{array}$ & $\begin{array}{l}\text { Formulating values } \\
\text { proved to be a very } \\
\text { good way to get to the } \\
\text { point and summarize } \\
\text { the essence of the re- } \\
\text { sults so far. It forced } \\
\text { the project team to } \\
\text { critically think about } \\
\text { the overall added val- } \\
\text { ue and goals of the } \\
\text { VR app and prevented } \\
\text { them from getting lost } \\
\text { in details or a tunnel } \\
\text { vision }\end{array}$ & $\begin{array}{l}\text { Values might be difficult to under- } \\
\text { stand for outsiders as they are ab- } \\
\text { stract, concise summaries of the } \\
\text { needs and wishes. Consequently, } \\
\text { clear definitions of the values were } \\
\text { provided to prevent misunderstand- } \\
\text { ings. } \\
\text { Besides their importance for devel- } \\
\text { opment, the project team deter- } \\
\text { mined that values could also be } \\
\text { useful to determine what to evalu- } \\
\text { ate: to what extent was the added } \\
\text { value actually achieved in practice? } \\
\text { This way of thinking about values } \\
\text { allowed the project team to think } \\
\text { ahead in terms of implementation } \\
\text { and evaluation and facilitated a } \\
\text { broader view on the VR application. } \\
\text { In hindsight, the process of formu- } \\
\text { lating values was more complex } \\
\text { than expected. The project team had } \\
\text { to account for the results of all used } \\
\text { research methods, combine them in } \\
\text { an abstract way, and make decisions } \\
\text { about conflicting values, such as } \\
\text { the importance of visual realism. A } \\
\text { clear guideline for formulating val- } \\
\text { ues would have been useful. }\end{array}$ \\
\hline
\end{tabular}

Generating a concept for a VR application based on the values and previously gathered results
Investigating (1) how far the stakeholders' opinions of the concept match the previously formulated values and (2) if changes to the concept are required for it to optimally fit the stakeholders' preferences
Idea generation - pro- Not appli- The main goal of the totyping: The project cable team discussed the values, attributes, and outcomes of all research activities and their implications for a VR application. Via multiple brainstorming sessions in which multiple low-fidelity prototypes were created, a first version of an idea was developed
The developed concept was a combination of elements of all 6 videos that were created by the project team. Also, important concepts that already arose from the interviews were present in the idea, for example, personalization, skills training, and new insights
- To ensure the consistency of the development process, the idea generation process started with discussing the implications of all earlier conducted studies, even though it was more appealing for the project team to start creating the idea right away.

- Visualization of ideas via low fidelity (lo-fi) prototypes appeared to work well during the idea generation process to make abstract concepts more concrete. For example, the team drew multiple dashboards and visualized the structure of the dashboard with post-its. This was experienced as helpful by all members of the project team.
Overall, the idea fits the values of the participant, mostly with regard to the unique added value to treatment. No major changes to the basic idea were necessary. In later stages, attention should be paid to the usability of the application, training, and protocols to successfully embed VR in treatment 


\begin{tabular}{|c|c|c|c|c|}
\hline Research goal & Method & $\begin{array}{l}\text { Target } \\
\text { group }\end{array}$ & Main results & Lessons learned \\
\hline & $\begin{array}{l}\text { Interviews-idea final- } \\
\text { ization: In the first } \\
\text { part, open-ended } \\
\text { questions, based on an } \\
\text { adapted version of the } \\
\text { TAM }{ }^{\mathrm{c}} \text { [41], were } \\
\text { asked to check the atti- } \\
\text { tudes toward the con- } \\
\text { cept of the VR applica- } \\
\text { tion. The second part } \\
\text { focused on the partici- } \\
\text { pant's overall opinion } \\
\text { of the VR application. } \\
\text { The developed low-fi- } \\
\text { delity prototype and a } \\
\text { scenario on its use in } \\
\text { treatment were used }\end{array}$ & & $\begin{array}{l}\text { The first part was } \\
\text { coded deductively us- } \\
\text { ing the constructs of } \\
\text { the TAM (see Multi- } \\
\text { media Appendix 1: } \\
\text { 1.10), the second part } \\
\text { was coded deductive- } \\
\text { ly with the } 13 \text { formu- } \\
\text { lated values (see Mul- } \\
\text { timedia Appendix 1: } \\
\text { 1.11). Overall, the } \\
\text { idea was evaluated } \\
\text { positively, but there } \\
\text { were some concerns } \\
\text { about the ease of use } \\
\text { of the application. All } \\
\text { values were, to some } \\
\text { extent, present in the } \\
\text { participants' answers. } \\
\text { Most positive remarks } \\
\text { were about the added } \\
\text { value for treatment, } \\
\text { for example, fit with } \\
\text { patient and new in- } \\
\text { sights. Points of atten- } \\
\text { tion were related to } \\
\text { the implementation in } \\
\text { treatment }\end{array}$ & $\begin{array}{l}\text { - This second set of interviews was } \\
\text { considerably shorter than the first } \\
\text { one: they only took about } 15 \text { to } 20 \\
\text { minutes. It proved to be easier to } \\
\text { include patients, which might be } \\
\text { because of the relatively little time } \\
\text { that was required to participate. } \\
\text { Using the values to code these inter- } \\
\text { views was useful to determine the } \\
\text { positive and negative aspects of the } \\
\text { idea in relation to the added value } \\
\text { that it should have had. In this way, } \\
\text { it became very clear what the points } \\
\text { of improvements were, which might } \\
\text { not have been the case with an in- } \\
\text { ductive, bottom-up coding process. } \\
\text { It also allowed the project team to } \\
\text { check whether the idea was still in } \\
\text { line with the values. } \\
\text { The TAM was used in the interview } \\
\text { scheme and coding process. Al- } \\
\text { though it helped to structurally ask } \\
\text { about and analyze the participants' } \\
\text { attitudes and intentions, it provided } \\
\text { hardly any information about the } \\
\text { treatment context and characteris- } \\
\text { tics of (other) persons [ } 42,43 \text { ]. The } \\
\text { second part, in which the added } \\
\text { have sufficed in this interview. } \\
\text { peared to be necessary to paint a } \\
\text { full picture of the participants' } \\
\text { opinion. }\end{array}$ \\
\hline
\end{tabular}

${ }^{\mathrm{a}} \mathrm{VR}$ : virtual reality.

${ }^{\mathrm{b}} \mathrm{PII}$ : personal involvement inventory.

${ }^{\mathrm{c}}$ TAM: technology acceptance model.

\section{Discussion}

\section{Reflection on Development Methods}

The main goals of this study were to analyze the suitability of the development methods for participatory eHealth development in a complex context and reflect on the development model used: the CeHRes Roadmap. This study can contribute to the development of a broad tool kit from which researchers can choose appropriate methods for the stage of their development process, participants, and context. In hindsight, this study would have benefited from such a tool kit, as the results showed that all methods generated valuable information, but not each method proved to be very suitable for the target group and their context. Besides generating knowledge on suitable methods, this type of study can also facilitate reflection and accompanying improvements of the development model used. Although this study offers a contribution, more studies that pay attention to development methods and models are required to make generalizable statements about methods and models.

The first goal of this study was to reflect on the suitability of different development methods. The relevance of this goal became clear from the experiences of the project team, as a major challenge was to identify the suitable methods for the forensic psychiatric patient population. These types of vulnerable patient populations are often difficult to involve in research, and not much is known about the suitable methods for these types of population $[27,44]$. On the basis of the experiences with methods used in this study, several conclusions and recommendations can be drawn on the suitability of methods.

A first set of recommendations focuses on involving patients in research. First of all, working with concrete examples seemed to work better than merely asking patients for their opinion or ideas without much guidance or input [4]. Using existing or potential examples is also possible in the earliest stages of the process, when not much is known yet, and can be done by using methods derived from a human-centered design, such as scenarios, personas, or prototypes $[45,46]$. A second recommendation based on the findings of this study is to keep data collection as short as possible, because patients might have difficulties with concentration or are not motivated to invest a lot of time. This recommendation is also relevant for health care professionals, because although researchers often want to collect 
as much data as possible, the professionals often not have a lot of time to participate [17]. The balance between how much in-depth information should be collected and the duration of data collection was experienced as difficult, so more research on this topic is needed. Finally, participating in research should be perceived as personally relevant or rewarding [47]. Although we used rewards such as VR goggles in the questionnaire and interviews, including participants for the focus groups proved to be easier. A reason for this might have been that participants could experience VR during the focus groups, which was perceived as new and exciting by both patients and therapists. Consequently, it appears to be worthwhile to spend time on identifying personally relevant rewards for participants.

The second set of recommendations centers on combining multiple methods and perspectives to paint a clear and complete picture of the context and stakeholder perspective. First, although involving patients proved to be very valuable, the development process also benefited from the perspectives of other types of stakeholders, such as therapists, managers, researchers, and technology developers, as they might have different needs or a more overarching view [28,48]. For example, the analysis of the first set of interviews showed that patients mostly mentioned the use of VR to observe situations and stimuli, whereas therapists also pointed out the importance of other possibilities, such as skill training, which was not mentioned by the patients. Second, involving participants via multiple methods enabled the project team to gain different types of information that supported them in getting a good grasp of all perspectives on VR in forensic mental health care. Finally, it can be concluded that more knowledge on suitable methods for involving patients, therapists, and other stakeholders in eHealth development is needed to be able to make more generalizable statements and create a tool kit [47].

\section{Operationalization of the Development Model}

Besides reflections on development methods, this study also aimed to reflect on the application of the development model that was used: the CeHRes Roadmap. It is of course not possible to conclude whether the development process guided by the CeHRes Roadmap resulted in better outcomes than another development method, partly because that would require 2 parallel development processes in identical settings [18], which is difficult both practically and conceptually. Nevertheless, based on the experiences of the project team, it can be concluded that the CeHRes Roadmap provided a valuable guidance for the development process. This process resulted in a concept for a VR application that is based on the wishes and preferences of the therapists and patients. The fit with their wishes became especially clear in the second round of interviews that showed that participants were enthusiastic about the concept and their opinions closely matched the previously formulated values.

On the basis of the experiences of this study, several recommendations can be made on how to operationalize the CeHRes Roadmap and similar development models. First of all, an important principle of eHealth development is that it should comprise multiple formative evaluation cycles. The experiences of this study confirmed that the Roadmap should not be used as a linear, sequential approach with a fixed order of phases and accompanying activities [18]. To illustrate, the first set of interviews and focus groups provided information that was relevant for both the contextual inquiry and value specification phase. Also, during the value specification, activities from the design phase, such as prototyping and scenarios, were used to elicit opinions. Consequently, although the phases of the Roadmap are visualized as separate blocks (see Figure 1), they should be used as overlapping, interwoven sets of principles and methodologies. A thorough understanding of the principles of the Roadmap appeared to be more important than strictly following the order of separate phases.

A second important finding was that the formulation of clear, specific research goals was pivotal in structuring this development process. A pitfall of an elaborate development process in a complex setting is that it might become unstructured or vague $[6,14]$. We tried to prevent this by formulating multiple clear, specific research questions that were based on the goals of the Roadmap's phases and its 5 underlying principles [6]. To keep the process coherent, the project team carefully thought about how these research questions related to the outcomes of the previous development activities. Also, we added multiple formative evaluations to check whether the outcomes of different activities remained consistent with each other. This process is visualized in Figure 3.

Third, although constituting and managing an interdisciplinary project team was complex and time-consuming, the team was found to be an important part of the development process as it facilitated decision making from multiple perspectives $[22,49,50]$. Multidisciplinary teamwork in health care is often complex [51], so several measures were taken to increase the chances on a successful collaboration. Among other things, patients and therapists that participated in the project team were involved as active co-designers instead of passive informants $[52,53]$ and thus took part in activities, such as designing studies, interpreting results, and creating and adapting ideas. To achieve this, the project leader ensured that each project team member had a clear task, as was, for example, done in the creation of scenarios, where each member actively participated in creating an idea and writing the script for 2 of the videos. Fourth, much attention was paid to the functioning of the team. Among other things, roles and tasks of all team members were made clear; regular, bimonthly meetings were held and there was ample communication in between meetings; individual members got the opportunity to be involved in activities of their own choice; there was a mix of skills and interests of members; there was a positive climate of trust and common respect; and, importantly, the team had a common, clear goal [51]. However, as these findings are based on only 1 development process, they are not generalizable. As the functioning of a project team seems to be a relevant topic in eHealth development, more studies on how to compose and organize multidisciplinary project teams should be conducted to be able to draw generalizable conclusions and recommendations. Finally, when operationalizing the CeHRes Roadmap —or any other development model—a thorough understanding of the model's underlying principles, continuous formative evaluations to prevent tunnel vision, clear research questions with suitable methods, and a well-functioning multidisciplinary team were found to be important. 
Figure 3. The structure of the goal-driven development process with multiple formative evaluation cycles.

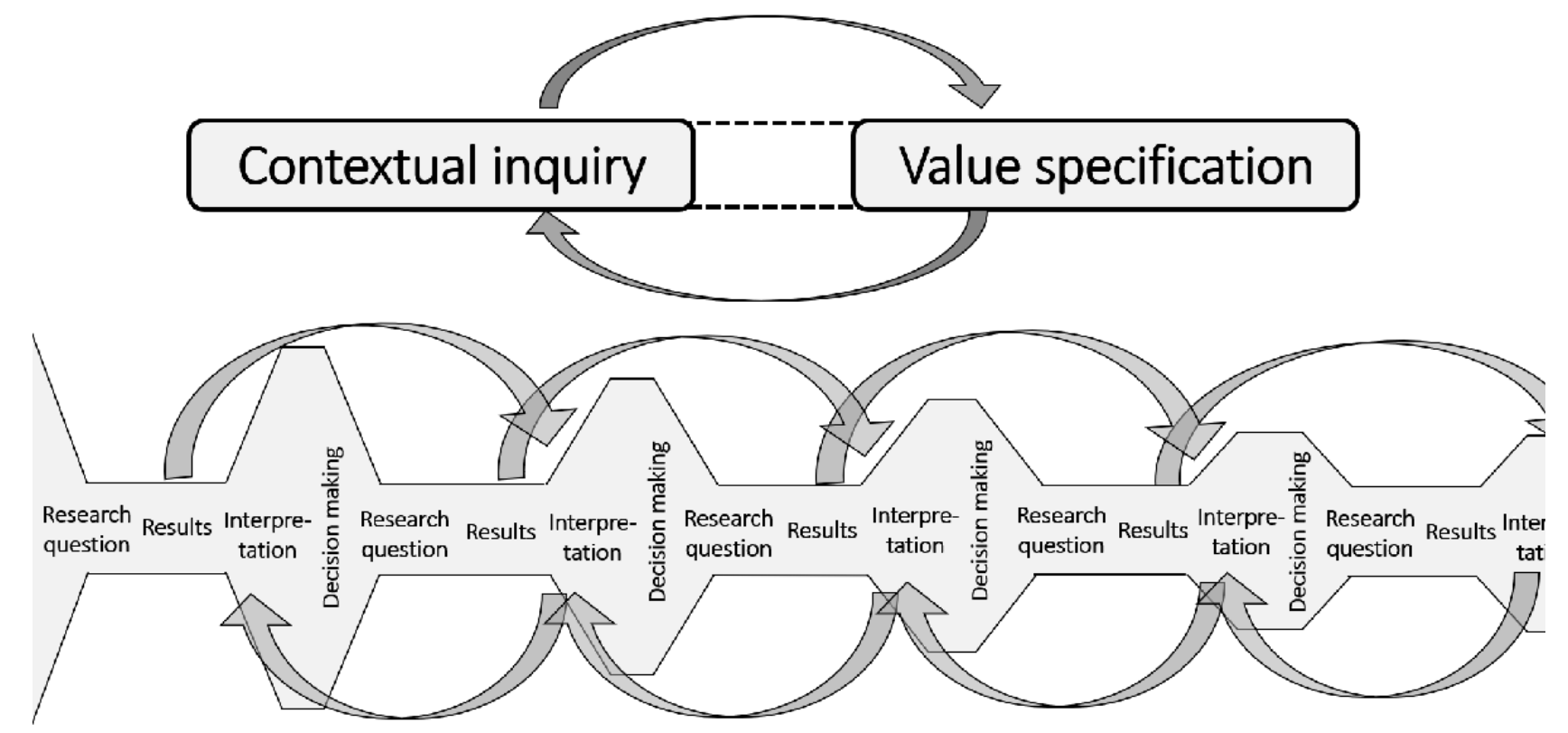

\section{Reflection on the CeHRes Roadmap}

While using the CeHRes Roadmap to shape the development process, we identified several strong points but also some points of improvement. First of all, the participatory development principle was used to determine what the main goal of the VR application should be in a bottom-up manner. According to this principle, it is important to involve users from the start to ensure that a technology addresses actual problems or points of improvement and is of added value for them [54]. However, in many cases, the goal of an eHealth technology is determined by researchers and/or developers, and stakeholders are involved as mere informants in later stages to provide feedback on concepts that were created in a top-down manner [55]. In this project, we tried to prevent this by actively involving stakeholders from the start, among other things, by asking them about points of improvement of the current situation and enabling them to come up with their own ideas about VR. Further along the process, values were formulated to specify the goal of the VR application. These values forced the project team to explicitly state the added value that a technology should have for patients and therapists. However, during the value specification, we noticed that there was a lack of clear guidelines on how to formulate these values and what topics they should cover. Although this value-driven approach was experienced as useful to keep an eye on people and their context, there is still much uncharted territory. We recommend that more studies using values in their development process should be conducted to be able to create clear guidelines.

Second, the Roadmap emphasizes the importance of formative evaluation and use of multiple methods. This indeed proved to be essential in this development process, especially because at the start of the project, there was no knowledge about the use of VR in forensic treatment. Consequently, much information had to be generated to make substantiated choices for the goal and content of the VR app. Just using 1 or 2 research methods would not have sufficed. This can be illustrated by the following example on personalization of VR. The first interviews and literature study indeed pointed out that personalization was important [35-37] but did not provide in-depth information about this topic. The results of the questionnaire offered more insights into what stakeholders wanted to be able to personalize: virtual people, environments, and scenarios. Throughout the process, the project team further specified these preferences and translated them into concepts for personalized VR applications via low-fidelity prototypes that were evaluated with stakeholders and fine-tuned accordingly. If only 1 interview study would have been conducted, the project team would not have had enough input to create a personalized VR application. A disadvantage of the multimethod, iterative approach was that it was very time-consuming. It might be possible that, if more would have been known about VR in forensic mental health care or suitable development methods, less research would have been required, which might have resulted in a shorter and more efficient development process. But again, more research on different types of development methods is required to draw more conclusions on this topic.

Finally, when reflecting on the development process, a more systematic approach toward involving domain-specific theories and models could have been used. Owing to the involvement of researchers and professionals with much knowledge on existing treatment models and theories on offending, this information was included but in an ad hoc manner. As other studies and models such as intervention mapping point out, it is important to incorporate theories that explain and change behavior in eHealth interventions [7,12,56,57]. In this project, this relates to models that explain delinquent behavior or theories that underpin treatment of forensic psychiatric patients, such as 
the general theory of crime [58] or the risk-need-responsivity model [59]. Consequently, we recommend that the use of domain-specific theories and models to explain behavior and treatment can be explicitly integrated in the Roadmap. To do this, the pillar on persuasive design could be adapted. In its current state, it focuses on behavior change via persuasive design. We suggest a change to this pillar, so that, besides persuasive theory, it also entails the use of domain-specific theories and models throughout the entire development process. Goals and activities derived from this adapted principle could be added to the contextual inquiry and value specification phases to add more focus on domain-specific theories at the beginning of the development process.

\section{Conclusions}

This study described and reflected on the methods and development model used in a development process of a VR application for a complex setting: forensic mental health care. To take the domain of eHealth development to the next level, more studies need to report and reflect on the development processes in a standardized way to generate more knowledge on suitable methods. This might result in a tool kit that researchers can use to choose and operationalize methods. Based on this study, we conclude that eHealth development is much more than programing a technology or just going with the flow; it requires thorough research via methods that fit the participants, stage in the development process and context, structured project coordination by a multidisciplinary project team, a flexible and open mind-set, and the inclusion of multiple perspectives in every decision.

\section{Acknowledgments}

Funding for this study was provided by Stichting Vrienden van Oldenkotte. The authors would like to thank the members of the VooRuit met VR project team for their valuable contributions to this project: Dirk Dijkslag, Kirby Weerink, Ron Voorhuis, Jakob Visser, Kevin Krimmel, and Anne Marike Halma. A special thanks to Ankie Kuiper and Ines Brünninghoff for their work in analyzing the questionnaire and conducting the second set of interviews and to Kirby Weerink for conducting the first round of interviews.

\section{Conflicts of Interest}

None declared.

\section{Multimedia Appendix 1}

Main results of the research methods.

[PDF File (Adobe PDF File), 1MB-Multimedia Appendix 1]

\section{References}

1. van Gemert-Pijnen L, Kip H, Kelders SM, Sanderman R. Introducing ehealth. In: van Gemert-Pijnen L, Kelders SM, Kip H, Sanderman R, editors. eHealth Research, Theory and Development: A Multi-Disciplinary Approach. London: Routledge; 2018:23-46.

2. Mohr DC, Schueller SM, Montague E, Burns MN, Rashidi P. The behavioral intervention technology model: an integrated conceptual and technological framework for ehealth and mhealth interventions. J Med Internet Res 2014 Jun 5;16(6):e146 [FREE Full text] [doi: 10.2196/jmir.3077] [Medline: 24905070]

3. van Gemert-Pijnen L, Peters O, Ossebaard HC, editors. Improving eHealth. The Netherlands: Eleven International Publishing; 2013.

4. Beerlage-de Jong N. eHealth vs Infection: Participatory Development of Persuasive eHealth to Support Safe Care. The Netherlands: University Library/University of Twente; 2016.

5. Pieterse ME, Kip H, Cruz-Martínez RR. The complexity of ehealth implementation: a theoretical and practical perspective. In: van Gemert-Pijnen L, Kelders SM, Kip H, Sanderman R, editors. eHealth Research, Theory and Development: A Multi-Disciplinary Approach. London: Routledge; 2018:247-270.

6. Kip H, van Gemert-Pijnen L. Holistic development of ehealth technology. In: van Gemert-Pijnen L, Kelders SM, Kip H, Sanderman R, editors. eHealth Research, Theory and Development: A Multi-Disciplinary Approach. London: Routledge; 2018:151-186.

7. Michie S, Yardley L, West R, Patrick K, Greaves F. Developing and evaluating digital interventions to promote behavior change in health and health care: recommendations resulting from an international workshop. J Med Internet Res 2017 Dec 29;19(6):e232 [FREE Full text] [doi: 10.2196/jmir.7126] [Medline: 28663162]

8. Patrick K, Hekler EB, Estrin D, Mohr DC, Riper H, Crane D, et al. The pace of technologic change: implications for digital health behavior intervention research. Am J Prev Med 2016 Dec;51(5):816-824. [doi: 10.1016/j.amepre.2016.05.001] [Medline: 27745681]

9. van Gemert-Pijnen JE, Nijland N, van Limburg M, Ossebaard HC, Kelders SM, Eysenbach G, et al. A holistic framework to improve the uptake and impact of ehealth technologies. J Med Internet Res 2011 Dec 5;13(4):e111 [FREE Full text] [doi: 10.2196/jmir.1672] [Medline: 22155738] 
10. Yardley L, Morrison L, Bradbury K, Muller I. The person-based approach to intervention development: application to digital health-related behavior change interventions. J Med Internet Res 2015 Jan 30;17(1):e30 [FREE Full text] [doi: 10.2196/jmir.4055] [Medline: 25639757]

11. Mohr DC, Lyon AR, Lattie EG, Reddy M, Schueller SM. Accelerating digital mental health research from early design and creation to successful implementation and sustainment. J Med Internet Res 2017 Dec 10;19(5):e153 [FREE Full text] [doi: 10.2196/jmir.7725] [Medline: 28490417]

12. Eldredge LK, Markham CM, Ruiter RA, Fernández ME, Kok G, Parcel GS. Planning Health Promotion Programs: An Intervention Mapping Approach. Hoboken, New Jersey: John Wiley \& Sons; 2016.

13. Oinas-Kukkonen H, Harjumaa M. Persuasive systems design: key issues, process model, and system features. Commun Assoc Inf Syst 2009;24(1):28. [doi: 10.17705/1CAIS.02428]

14. Hekler EB, Klasnja P, Riley WT, Buman MP, Huberty J, Rivera DE, et al. Agile science: creating useful products for behavior change in the real world. Transl Behav Med 2016 Dec;6(2):317-328 [FREE Full text] [doi: 10.1007/s13142-016-0395-7] [Medline: 27357001]

15. van Gemert-Pijnen L, Kelders SM, Kip H, Sanderman R, editors. eHealth Research, Theory and Development: A Multi-Disciplinary Approach. London: Routledge; 2018.

16. Wentzel J, van Velsen L, van Limburg M, de Jong N, Karreman J, Hendrix R, et al. Participatory ehealth development to support nurses in antimicrobial stewardship. BMC Med Inform Decis Mak 2014 Jun 5;14:45 [FREE Full text] [doi: 10.1186/1472-6947-14-45] [Medline: 24898694]

17. van Velsen L, Wentzel J, van Gemert-Pijnen JE. Designing ehealth that matters via a multidisciplinary requirements development approach. JMIR Res Protoc 2013 Jun 24;2(1):e21 [FREE Full text] [doi: 10.2196/resprot.2547] [Medline: 23796508]

18. Kelders SM, Pots WT, Oskam MJ, Bohlmeijer ET, van Gemert-Pijnen JE. Development of a web-based intervention for the indicated prevention of depression. BMC Med Inform Decis Mak 2013 Feb 20;13:26 [FREE Full text] [doi: 10.1186/1472-6947-13-26] [Medline: 23425322]

19. van der Weegen S, Verwey R, Spreeuwenberg M, Tange H, van der Weijden T, de Witte L. The development of a mobile monitoring and feedback tool to stimulate physical activity of people with a chronic disease in primary care: a user-centered design. JMIR Mhealth Uhealth 2013 Jul 2;1(2):e8 [FREE Full text] [doi: 10.2196/mhealth.2526] [Medline: 25099556]

20. Wolpin SE, Halpenny B, Whitman G, McReynolds J, Stewart M, Lober WB, et al. Development and usability testing of a web-based cancer symptom and quality-of-life support intervention. Health Informatics J 2015 Mar;21(1):10-23 [FREE Full text] [doi: 10.1177/1460458213495744] [Medline: 24406906]

21. Beerlage-de Jong N, van Gemert-Pijnen L, Wentzel J, Hendrix R, Siemons L. Technology to support integrated antimicrobial stewardship programs: a user centered and stakeholder driven development approach. Infect Dis Rep 2017 Mar 30;9(1):6829 [FREE Full text] [doi: 10.4081/idr.2017.6829] [Medline: 28458796]

22. Geissbuhler A. Lessons learned implementing a regional health information exchange in Geneva as a pilot for the Swiss national ehealth strategy. Int J Med Inform 2013 May;82(5):e118-e124. [doi: 10.1016/j.ijmedinf.2012.11.002] [Medline: 23332387]

23. Covvey HD. Healthcare as a complex adaptive system. In: van Gemert-Pijnen L, Kelders SM, Kip H, Sanderman R, editors. eHealth Research, Theory and Development: A Multi-Disciplinary Approach. London: Routledge; 2018:89-110.

24. Greenhalgh T, Wherton J, Papoutsi C, Lynch J, Hughes G, A'Court C, et al. Beyond adoption: a new framework for theorizing and evaluating nonadoption, abandonment, and challenges to the scale-up, spread, and sustainability of health and care technologies. J Med Internet Res 2017 Dec 1;19(11):e367 [FREE Full text] [doi: 10.2196/jmir.8775] [Medline: 29092808]

25. Ross J, Stevenson F, Lau R, Murray E. Factors that influence the implementation of e-health: a systematic review of systematic reviews (an update). Implement Sci 2016 Dec 26;11(1):146 [FREE Full text] [doi: 10.1186/s13012-016-0510-7] [Medline: 27782832]

26. Sieverink F, Köhle N, Cheung K, Roefs A, Trompetter H, Keizer J, et al. Evaluating ehealth. In: van Gemert-Pijnen L, Kelders SM, Kip H, Sanderman R, editors. eHealth Research, Theory and Development: A Multi-Disciplinary Approach. London: Routledge; 2018.

27. Flaskerud JH, Winslow BJ. Conceptualizing vulnerable populations health-related research. Nurs Res 1998;47(2):69-78. [doi: 10.1097/00006199-199803000-00005] [Medline: 9536190]

28. Kip H, Bouman YH, Kelders SM, van Gemert-Pijnen LJ. eHealth in treatment of offenders in forensic mental health: a review of the current state. Front Psychiatry 2018;9:42 [FREE Full text] [doi: 10.3389/fpsyt.2018.00042] [Medline: 29515468]

29. Kip H, Kelders SM, Weerink K, Kuiper A, Brüninghoff I, Bouman YH, et al. Identifying the added value of virtual reality for treatment in forensic mental health: a scenario-based, qualitative approach. Front Psychol 2019;10:406 [FREE Full text] [doi: 10.3389/fpsyg.2019.00406] [Medline: 30873093]

30. Kip H, Kelders SM, van Gemert-Pijnen LJ. Putting the Value in VR: How to Systematically and Iteratively Develop a Value-Based VR Application with a Complex Target Group. In: Proceedings of the 2019 CHI Conference on Human Factors in Computing Systems. 2019 Presented at: CHI'19; May 4-9, 2019; Glasgow, Scotland UK. [doi: 10.1145/3290605.3300365] 
31. van Woezik AF, Braakman-Jansen LM, Kulyk O, Siemons L, van Gemert-Pijnen JE. Tackling wicked problems in infection prevention and control: a guideline for co-creation with stakeholders. Antimicrob Resist Infect Control 2016;5:20 [FREE Full text] [doi: 10.1186/s13756-016-0119-2] [Medline: 27213040]

32. Renaud P, Trottier D, Rouleau J, Goyette M, Saumur C, Boukhalfi T, et al. Using immersive virtual reality and anatomically correct computer-generated characters in the forensic assessment of deviant sexual preferences. Virtual Real 2013 Oct 30;18(1):37-47. [doi: 10.1007/s10055-013-0235-8]

33. Fromberger P, Meyer S, Kempf C, Jordan K, Müller JL. Virtual viewing time: the relationship between presence and sexual interest in androphilic and gynephilic men. PLoS One 2015;10(5):e0127156 [FREE Full text] [doi: 10.1371/journal.pone.0127156] [Medline: 25992790]

34. Renaud P, Chartier S, Rouleau J, Proulx J, Goyette M, Trottier D, et al. Using immersive virtual reality and ecological psychology to probe into child molesters' phenomenology. J Sex Aggress 2011 Nov 8;19(1):102-120. [doi: 10.1080/13552600.2011.617014]

35. Renaud P, Rouleau JL, Proulx J, Trottier D, Goyette M, Bradford JP, et al. Virtual characters designed for forensic assessment and rehabilitation of sex offenders: standardized and made-to-measure. J Virtual Real Broadcast 2010;7(5):1-9. [doi: $10.20385 / 1860-2037 / 7.2010 .5]$

36. Fromberger P, Jordan K, Müller JL. [Use of virtual reality in forensic psychiatry. A new paradigm?]. Nervenarzt 2014 Mar;85(3):298-303. [doi: 10.1007/s00115-013-3904-7] [Medline: 24549691]

37. Benbouriche M, Nolet K, Trottier D, Renaud P. Virtual Reality Applications in Forensic Psychiatry. In: Proceedings of the 2014 Virtual Reality International Conference. 2014 Presented at: VRIC'14; April 9-11, 2014; Laval, France. [doi: $10.1145 / 2617841.2620692]$

38. YouTube. 2018. Vooruit met VR URL: https://www.youtube.com/ playlist?list=PLPPQsPUGLUhmgEKfTAr0wJ6UemosnAsiS [accessed 2018-01-04]

39. Kelders SM. Involvement as a Working Mechanism for Persuasive Technology. In: Proceedings of the International Conference on Persuasive Technology. 2015 Presented at: PERSUASIVE'15; June 3-5, 2015; Chicago, IL, USA p. 3-14. [doi: $\left.10.1007 / 978-3-319-20306-5 \_1\right]$

40. Zaichkowsky JL. The personal involvement inventory: reduction, revision, and application to advertising. J Advert 1994 Dec;23(4):59-70. [doi: 10.1080/00913367.1943.10673459]

41. Venkatesh V, Davis FD. A theoretical extension of the technology acceptance model: four longitudinal field studies. Manage Sci 2000 Feb;46(2):186-204. [doi: 10.1287/mnsc.46.2.186.11926]

42. van Velsen L, Evers M, Bara CD, den Akker HO, Boerema S, Hermens H. Manage sciunderstanding the acceptance of an ehealth technology in the early stages of development: an end-user walkthrough approach and two case studies. JMIR Form Res 2018 Jun 15;2(1):e10474 [FREE Full text] [doi: 10.2196/10474] [Medline: 30684434]

43. Legris P, Ingham J, Collerette P. Why do people use information technology? A critical review of the technology acceptance model. Inform Manage 2003 Jan;40(3):191-204. [doi: 10.1016/S0378-7206(01)00143-4]

44. Emergency Preparedness and Response |CDC. 2010. Public Health Workbook: To Define, Locate, and Reach Special, Vulnerable, and At-Risk Populations in an Emergency URL: https://emergency.cdc.gov/workbook/pdf/ph workbookfinal. pdf

45. Beerlage-de Jong N, Wentzel J, Hendrix R, van Gemert-Pijnen L. The value of participatory development to support antimicrobial stewardship with a clinical decision support system. Am J Infect Control 2017 Apr 1;45(4):365-371. [doi: 10.1016/j.ajic.2016.12.001] [Medline: 28089673]

46. Burns C. Human-centred design. In: van Gemert-Pijnen L, Kelders SM, Kip H, Sanderman R, editors. eHealth Research, Theory and Development: A Multi-Disciplinary Approach. London: Routledge; 2018.

47. Dugas M, Trottier ME, Dansokho SC, Vaisson G, Provencher T, Colquhoun H, et al. Involving members of vulnerable populations in the development of patient decision aids: a mixed methods sequential explanatory study. BMC Med Inform Decis Mak 2017 Jan 19;17(1):12 [FREE Full text] [doi: 10.1186/s12911-016-0399-8] [Medline: 28103862]

48. van der Vaart R, Witting M, Riper H, Kooistra L, Bohlmeijer ET, van Gemert-Pijnen LJ. Blending online therapy into regular face-to-face therapy for depression: content, ratio and preconditions according to patients and therapists using a Delphi study. BMC Psychiatry 2014 Dec 14;14:355 [FREE Full text] [doi: 10.1186/s12888-014-0355-z] [Medline: 25496393]

49. Feldman SS, Schooley BL, Bhavsar GP. Health information exchange implementation: lessons learned and critical success factors from a case study. JMIR Med Inform 2014 Aug 15;2(2):e19 [FREE Full text] [doi: 10.2196/medinform.3455] [Medline: 25599991]

50. Nielsen JA, Mathiassen L. Interpretive flexibility in mobile health: lessons from a government-sponsored home care program. J Med Internet Res 2013 Oct 30;15(10):e236 [FREE Full text] [doi: 10.2196/jmir.2816] [Medline: 24172852]

51. Nancarrow SA, Booth A, Ariss S, Smith T, Enderby P, Roots A. Ten principles of good interdisciplinary team work. Hum Resour Health 2013 May 10;11:19 [FREE Full text] [doi: 10.1186/1478-4491-11-19] [Medline: 23663329]

52. DeSmet A, Thompson D, Baranowski T, Palmeira A, Verloigne M, de Bourdeaudhuij I. Is participatory design associated with the effectiveness of serious digital games for healthy lifestyle promotion? A meta-analysis. J Med Internet Res 2016 Apr 29;18(4):e94 [FREE Full text] [doi: 10.2196/jmir.4444] [Medline: 27129447] 
53. Yip J, Clegg T, Bonsignore E, Gelderblom H, Rhodes E, Druin A. Brownies or Bags-of-Stuff?: Domain Expertise in Cooperative Inquiry With Children. In: Proceedings of the 12th International Conference on Interaction Design and Children. 2013 Presented at: IDC'13; June 24-27, 2013; New York, USA p. 201-210. [doi: 10.1145/2485760.2485763]

54. Kip H, Beerlage-de Jong N, Wentzel J. The contextual inquiry. In: van Gemert-Pijnen JE, Kelders SM, Kip H, Sanderman R, editors. eHealth Research, Theory and Development: A Multi-Disciplinary Approach. London: Routledge; 2018:187-206.

55. Scaife M, Rogers Y, Aldrich F, Davies M. Designing for or Designing With? Informant Design for Interactive Learning Environments. In: Proceedings of the ACM SIGCHI Conference on Human Factors in Computing Systems. 1997 Presented at: CHI'97; March 22-27, 1997; Atlanta, Georgia, USA p. 343-350. [doi: 10.1145/258549.258789]

56. Moller AC, Merchant G, Conroy DE, West R, Hekler E, Kugler KC, et al. Applying and advancing behavior change theories and techniques in the context of a digital health revolution: proposals for more effectively realizing untapped potential. $\mathrm{J}$ Behav Med 2017 Feb;40(1):85-98 [FREE Full text] [doi: 10.1007/s10865-016-9818-7] [Medline: 28058516]

57. Webb TL, Joseph J, Yardley L, Michie S. Using the internet to promote health behavior change: a systematic review and meta-analysis of the impact of theoretical basis, use of behavior change techniques, and mode of delivery on efficacy. $\mathrm{J}$ Med Internet Res 2010 Feb 17;12(1):e4 [FREE Full text] [doi: 10.2196/jmir.1376] [Medline: 20164043]

58. Gottfredson MR. A General Theory Of Crime. Stanford: Stanford University Press; 1990.

59. Bonta J, Andrews DA. Risk-Need-Responsivity Model for Offender Assessment and Rehabilitation. Canada: Public Safety Canada; 2007.

\title{
Abbreviations \\ CeHRes: Centre for eHealth Research \\ eHealth: electronic health \\ PII: personal involvement inventory \\ TAM: technology acceptance model \\ VR: virtual reality
}

\author{
Edited by G Eysenbach; submitted 30.11.18; peer-reviewed by L van Velsen, C Prahm, E Bфrфsund; comments to author 31.03.19; \\ revised version received 26.04.19; accepted 10.06.19; published 19.08.19 \\ Please cite as: \\ Kip H, Kelders SM, Bouman YHA, van Gemert-Pijnen LJEWC \\ The Importance of Systematically Reporting and Reflecting on eHealth Development: Participatory Development Process of a Virtual \\ Reality Application for Forensic Mental Health Care \\ J Med Internet Res 2019;21(8):e12972 \\ URL: http://www.jmir.org/2019/8/e12972/ \\ doi: $10.2196 / 12972$ \\ PMID: 31429415
}

CHanneke Kip, Saskia M Kelders, Yvonne HA Bouman, Lisette JEWC van Gemert-Pijnen. Originally published in the Journal of Medical Internet Research (http://www.jmir.org), 19.08.2019. This is an open-access article distributed under the terms of the Creative Commons Attribution License (https://creativecommons.org/licenses/by/4.0/), which permits unrestricted use, distribution, and reproduction in any medium, provided the original work, first published in the Journal of Medical Internet Research, is properly cited. The complete bibliographic information, a link to the original publication on http://www.jmir.org/, as well as this copyright and license information must be included. 